\title{
Hvor stort gjennomslag har en medisinsk ordbok?
}

\begin{abstract}
Magne Nylenna skriver interessant og lærerikt i Tidsskriftet om de grundige prosessene som ligger bak produksjon og vedlikehold av en medisinsk ordbok (1). Imidlertid er det fare for at han overvurderer ordbokens betydning for «journalspråket», og fare for at hans gode navn og rykte er blitt misbrukt av Max Manus AS. Både overfor Nylenna og overfor sine kunder har dette firmaet altså hevdet at stavemåten i Medisinsk ordbok (2) er lagt til grunn i deres talegjenkjenningssystemer.

Virkeligheten er at talegjenkjenningssystemet til Max Manus AS er oversvømt av stavemåter som strider med den gode standard som Nylenna ønsker å legge til grunn. Dikterer man til Max Manus' system, skriver det «focal» når man sier fokal, «ischemi» når man sier iskemi, «vasculær» når man sier vaskulær, «syncope» når man sier synkope, «hjerte lunge redning» når man sier hjerte-lunge-redning, og så videre nærmest $\mathrm{i}$ det uendelige. Den sørgelige sannhet er at kommersielle aktører med sviktende språkøre og dårlige rutiner nok har atskillig større innflytelse på norsk medisinsk hverdagsspråk enn entusiastiske og grundige ordbokredaktører som filosoferer over korrekt ortografi i sene nattetimer.
\end{abstract}

\section{Torgeir Bruun Wyller}

t.b.wyller@medisin.uio.no

Geriatrisk avdeling

Oslo universitetssykehus, Ullevål

Oppgitte interessekonflikter: Ingen

Litteratur

1. Nylenna M. Hvordan lages en medisinsk ordbok? Tidsskr Nor Legeforen 2009; 129: 2401-2.

2. Nylenna M. Medisinsk ordbok. 7. utg. Oslo: Kunnskapsforlaget, 2009.

Manuskriptet ble mottatt 27.11. 2009 og godkjent 22.12. 2009. Medisinsk redaktør Raida Ødegaard. 